\title{
Effect of amount of milk replacer fed and the processing of corn in starter on growth performance, nutrient digestibility, and rumen and fecal fibrolytic bacteria of dairy calves
}

\author{
J. K. van Niekerk, ${ }^{1}$ A. J. Fischer-Tlustos, ${ }^{1 *}$ L. L. Deikun, ${ }^{2}$ J. D. Quigley, ${ }^{2}$ T. S. Dennis, ${ }^{2}$ F. X. Suarez-Mena, ${ }^{2}$ \\ T. M. Hill, ${ }^{2}$ R. L. Schlotterbeck, ${ }^{2}$ L. L. Guan, ${ }^{1}$ and M. A. Steele ${ }^{1 *} \dagger$ \\ ${ }^{1}$ Department of Agricultural, Food and Nutritional Science, University of Alberta, Edmonton, AB, T6G 2P5, Canada \\ ${ }^{2}$ Nurture Research Center, Provimi, Cargill Animal Nutrition, Brookville, $\mathrm{OH} 45309$
}

\section{ABSTRACT}

The aim of this study was to evaluate effects of milk replacer (MR) feeding rate and processing of corn in calf starter (CS) on growth performance, nutrient digestibility, and rumen and fecal fibrolytic bacteria in dairy calves. Holstein male calves $(\mathrm{n}=48,2-3 \mathrm{~d}$ of age) were randomly assigned to 1 of 4 treatments with a $2 \times 2$ factorial arrangement of MR level of $0.749 \mathrm{~kg}$ of $\mathrm{MR} / \mathrm{d}(\mathrm{LO})$ or up to $1.498 \mathrm{~kg}$ of $\mathrm{MR} / \mathrm{d}(\mathrm{HI})$; and whole corn or flaked corn in textured CS. Calves were weaned by reducing MR offered by $50 \%$ during wk 6 . Intakes of MR and CS were recorded daily, whereas body weight (BW) was measured weekly. Rumen fluid and fecal matter were collected at wk 5 and 8 to quantify fibrolytic bacteria and nutrient digestibility. Data were analyzed as a completely randomized design using mixed model ANOVA. Repeated measures were used as appropriate. Calves fed HI had greater average daily gain than calves fed LO at wk 2, 3, 4, and 5, yet at wk 7 calves fed HI had lower average daily gain compared with calves fed LO. Starter intake was greater for calves fed LO compared with $\mathrm{HI}$ at wk 4, 5, 6, and 7. During wk 5 and 8, calves fed LO had increased ADF and NDF digestibility compared with calves fed HI. During wk 5, dry matter and organic matter digestibility were lower for LO-fed calves compared with HI-fed calves, but during wk 8 the opposite was observed, with HIfed calves having lower dry matter and organic matter digestibility than LO-fed calves. At wk 5, Clostridium cluster IV and Butyrivibrio fibrisolvens proportions in rumen fluid tended to be higher and Clostridium cluster IV, Fecalibacterium sp., and Prevotella sp. proportions in fecal matter were higher in calves fed LO compared

Received July 31, 2019.

Accepted November 14, 2019.

*Current address: Department of Animal Biosciences, University of Guelph, Guelph, ON, N1G 2W1, Canada.

†Corresponding author: masteele@uoguelph.ca with HI. From wk 8 to 16, dry matter intake was unaffected by treatment; however, energy efficiency was greater in calves fed LO, causing LO calves to have higher BW gain during this period. Greater starter digestibility was observed for calves fed LO versus $\mathrm{HI}$ in concert with increased fibrolytic bacteria proportions (wk 5) in fecal and rumen samples, which resulted in greater postweaning $\mathrm{BW}$ gain and similar $\mathrm{BW}$ and frame measurements by 16 wk of age. Overall the results show that rate of MR feeding has a larger effect than the processing of corn in CS on performance, fiber digestibility, and rumen and fecal fibrolytic bacterial communities.

Key words: calf, milk replacer feeding, digestion, fibrolytic bacteria

\section{INTRODUCTION}

Recently, there has been interest in feeding dairy calves a higher volume of whole milk or milk replacer (MR) preweaning than the conventional rate of $10 \%$ of birth BW due to observed advantages during the preweaning phase, including improved weight gain (Jasper and Weary, 2002; Khan et al., 2011; Rosenberger et al., 2017) and improved feed efficiency (Khan et al., 2007a; Moallem et al., 2010; Davis Rincker et al., 2011). In addition, there is potential for heifer calves with increased preweaning ADG to have increased milk production later in life (Soberon et al., 2012; Soberon and Van Amburgh, 2013; Gelsinger et al., 2016). However, negative results of such feeding regimens have also been reported, such as poor performance (Cowles et al., 2006) and reduced feed efficiency during the weaning transition (liquid to solid feed) and thereafter (Hill et al., 2006). This is likely because preweaning starter intake is negatively influenced by a high MR feeding rate (Jasper and Weary, 2002; Jensen, 2006; Kristensen et al., 2007; Hill et al., 2009), resulting in diminished intake of calf starter (CS; Hill et al., 2006), leading to a delay in rumen development (Khan et al., 2016) 
that causes a reduction in nutrient digestibility, especially fiber, postweaning (Terré et al., 2007; Hill et al., 2010, 2016b). Inadequate rumen microbial fermentation caused by decreased CS intake when calves are fed higher volumes of milk or MR may result in a reduction in fiber digestion; however, the exact cause by which fiber digestion is decreased when calves are fed higher volumes of milk or MR is unknown. Therefore, further investigation regarding fibrolytic bacterial communities present in the rumen and feces is warranted.

The importance of supplying readily fermentable carbohydrates in CS is well established for its role in butyrate and propionate production in the rumen (Flatt et al., 1958; Sander et al., 1959). Corn is one of the ingredients most commonly used in CS and substituting corn with barley, oats, or wheat in CS resulted in reduced solid feed intake and weight gain in dairy calves up to 12 wk old (Khan et al., 2007b). Alteration (processing) of grains (e.g., grinding, steam- or dryrolling, and steam-flaking) enhances surface area for degradation, which leads to improved ruminal fermentation rate, passage rate, and total-tract starch digestibility in mature animals (Huntington, 1997). However, CS intake was increased when whole grains (corn and barley) were fed to calves compared with steam-rolled grains (Bateman et al., 2009; Terré et al., 2016). To date, most studies (Owens, et al., 1997; Firkins et al., 2001) have investigated effects of processing corn on mature animals (mainly dairy cows and feedlot animals) and research regarding the effect of feeding processed corn to dairy calves in CS is limited.

The objective of this study was to determine how the amount of MR and the processing of corn in CS can affect performance, nutrient digestibility, and the fibrolytic bacterial community in dairy calves. We hypothesized that feeding an elevated amount of MR with CS with whole corn would reduce nutrient digestion, resulting in poor performance.

\section{MATERIALS AND METHODS}

\section{Animals, Housing, and Environment}

A total of 48 Holstein bull calves ( \pm 3 d of age) were obtained from a single farm. Calves received $2 \mathrm{~L}$ of fresh colostrum within $1 \mathrm{~h}$ of birth followed by 2 additional feedings at 6 and $12 \mathrm{~h}$. Thereafter, calves were fed $2 \mathrm{~L}$ of pasteurized whole milk twice daily until being transported $(3.5 \mathrm{~h})$ to the Nurture Research Center (New Paris, OH). In this study, calves were cared for and handled in accordance with the Canadian Council on Animal Care (CCAC, 1993) regulations, Guide for the Care and Use of Agricultural Animals in Agricultural Research and Teaching (FASS, 1999), and the institu- tional Animal Care and Use Committee (University of Alberta, AB; AUP00002303).

This study consisted of 2 phases. In the first phase (nursery; wk 1 to 8 ), calves were housed in a barn with side curtains and natural ventilation in individual pens $(1.2 \mathrm{~m} \times 2.4 \mathrm{~m})$ bedded with wheat straw and given access to the experimental textured CS and fresh water ad libitum. Individual animal was the experimental unit. This phase consisted of 2 periods, pre- and postweaning at wk 1 to 6 and wk 7 to 8 , respectively. In phase 2 (grower; wk 9-16), calves were randomly assigned within nursery treatment to group pens $(\mathrm{n}=4$ calves/ pen) that provided $6.5 \mathrm{~m}^{2}$ per calf outside with inside shelter $\left(1.35 \mathrm{~m}^{2}\right.$ space per calf $)$ bedded with wheat straw. Pen ( $\mathrm{n}=3$ /treatment) was the experimental unit during the grower phase. During this phase, calves had access to a TMR consisting of CS and chopped grass hay (Table 1) in a 95:5 on an as-fed ratio. Calves were dehorned and castrated at d 36. Average temperature was $24^{\circ} \mathrm{C}$ (range $12-38^{\circ} \mathrm{C}$ ) and $19^{\circ} \mathrm{C}\left(\right.$ range $2-33^{\circ} \mathrm{C}$ ) for the nursery and grower phases, respectively. Average relative humidity was $79 \%$ (range $24-100 \%$ ) and $81 \%$ (range 24-100\%) for the nursery and grower phases, respectively.

\section{Experimental Design and Dietary Treatments}

The experiment was a completely randomized design with a $2 \times 2$ factorial arrangement of $0.749 \mathrm{~kg}$ of MR powder/d (LO) or up to $1.498 \mathrm{~kg}$ of $\mathrm{MR}$ powder/d (HI), and whole (WC) or flaked (FC) corn in a textured CS $(37 \%$ corn, $35 \%$ supplement pellet, $25 \%$ whole oats, and 3\% molasses; Table 1). Milk replacer (Table 1) contained $25.2 \% \mathrm{CP}, 17.9 \%$ fat on a DM basis and was reconstituted to $14 \%$ solids. Corn for WC and FC treatments was obtained from the same batch of corn to ensure similar composition between starch sources.

Table 1. Chemical composition of milk replacer (MR), starter, and hay (mean \pm SD) fed to dairy calves

\begin{tabular}{lcrr}
\hline Item & \multicolumn{1}{c}{ MR } & \multicolumn{1}{c}{ Starter $^{1}$} & \multicolumn{1}{c}{ Hay } \\
\hline DM, \% as fed & $93.1 \pm 1.13$ & $87.8 \pm 0.66$ & $86.2 \pm 2.1$ \\
DM basis, \% & & & \\
Ash & $5.9 \pm 0.33$ & $6.1 \pm 0.67$ & $8.3 \pm 1.14$ \\
CP & $25.2 \pm 0.57$ & $20.3 \pm 0.45$ & $6.6 \pm 0.91$ \\
Fat & $17.9 \pm 0.01$ & $3.6 \pm 0.22$ & $1.9 \pm 0.45$ \\
ADF & - & $7.2 \pm 0.50$ & $40.9 \pm 0.65$ \\
NDF & - & $15.4 \pm 1.14$ & $63.3 \pm 0.85$ \\
Starch & - & $41.5 \pm 0.86$ & $1.4 \pm 0.43$ \\
Sugar & 4.75 & $7.3 \pm 1.62$ & $8.8 \pm 1.49$ \\
ME $^{2}$ Mcal/kg & 3.26 & 2.05 \\
\hline
\end{tabular}

${ }^{1} 37 \%$ corn (either whole or steam flaked), $35 \%$ protein/mineral pellet, $25 \%$ whole oats, and $3 \%$ liquid molasses.

${ }^{2}$ Calculated using NRC (2001). 
Calves fed LO $(\mathrm{n}=24)$ received $0.749 \mathrm{~kg} / \mathrm{d}(\mathrm{DM}$ basis$)$ of MR for $6 \mathrm{wk}$, followed by $0.375 \mathrm{~kg} / \mathrm{d}$ of MR for the last week. Calves fed HI received $0.749 \mathrm{~kg} / \mathrm{d}$ of $\mathrm{MR}$ during wk $1,0.851 \mathrm{~kg} / \mathrm{d}$ during wk $2,1.135 \mathrm{~kg} / \mathrm{d}$ during wk $3,1.498 \mathrm{~kg} / \mathrm{d}$ during wk 4 and 5 , and $0.749 \mathrm{~kg} / \mathrm{d}$ of MR for the last week. Amounts of MR fed to calves were divided into 2 equal feedings (AM and $\mathrm{PM}$ ) until wk 6, when MR was only fed once (AM). All calves were weaned at the end of wk 6.

\section{Data and Sample Collection}

Intake and Growth Performance. During the pre- and postweaning period, individual MR and CS intakes were recorded daily and during the grower phase group pen intakes were recorded daily. Samples of MR and CS were taken from every second bag, whereas samples of hay were taken from every bale. Samples were composited by type and stored $\left(4^{\circ} \mathrm{C}\right)$ before chemical analysis. Individual BW was measured weekly (wk 1 to 8 ) pre- and postweaning and at wk 10, 12 , and 16 during the grower phase. Body condition score, adapted from Wildman et al. (1982), and hip width were measured every 2 wk. Hip height, heart girth, and paunch girth were measured at wk 0,8 , and 16. Efficiency was estimated by calculating total ME intake divided by BW gain.

Apparent Total-Tract Nutrient Digestibility. Fecal samples were collected over $5 \mathrm{~d}$, as described previously (Hill et al., 2016a), to estimate apparent total-tract digestibility. During wk 5 and 8, 6 calves from each treatment (total $\mathrm{n}=24$ ) were randomly selected for fecal sample collection. Samples were pooled by calf ( 5 d) by time point. During wk 11 to 12 , fecal samples were collected from the pen and were pooled $(5 \mathrm{~d})$ by pen. All fecal samples were stored at $-20^{\circ} \mathrm{C}$ before chemical analysis.

Fibrolytic Bacteria in Rumen and Feces. Ruminal fluid was sampled $4 \mathrm{~h}$ after AM feeding from the subset $(\mathrm{n}=24)$ of calves at wh 5 and 8 using a Geishauser probe (adapted for calves; Geishauser, 1993) fitted to a $60-\mathrm{mL}$ syringe. Ruminal contents were squeezed through 4 layers of cheesecloth and $8 \mathrm{~mL}$ of ruminal fluid was snap frozen (dry ice and ethanol mixture). Spot fecal samples were collected $3 \mathrm{~h}$ after the AM feeding from the same subset $(\mathrm{n}=24)$ of calves at wk 5 and 8 and snap frozen. Both samples (rumen and fecal) were stored at $-20^{\circ} \mathrm{C}$ before the quantification of the fibrolytic bacterial community.

\section{Sample Analyses}

Feed and Fecal Composition. Milk replacer, CS, hay, and fecal samples were analyzed (AOAC Inter- national, 2000) for DM (oven method 930.15), ash (oven method 942.05), CP (Kjeldahl method 988.05), fat (MR only; alkaline treatment with Roese-Gottlieb method 932.06), and acid-insoluble ash (Van Keulen and Young, 1977). Calf starter, hay, and fecal samples were analyzed for ADF (Robertson and Van Soest, 1981), NDF (Van Soest et al., 1991) without sodium sulfite or $\alpha$-amylase, ether extract (method 2003.05), sugar (colormetric method; DuBois et al., 1956), and starch ( $\alpha$-amylase method; Hall, 2009). Acid-insoluble ash measured in MR, CS, hay, and fecal samples was used as an internal digestibility marker (Van Keulen and Young, 1977). The ratio of acid-insoluble ash and nutrients in the feed and fecal matter was used to estimate apparent total-tract nutrient digestibility.

Quantification of Fibrolytic Bacteria in Rumen and Feces. The DNA was extracted from rumen fluid and fecal samples using the repeated bead beating plus column method (Yu and Morrison, 2004). Briefly, samples were treated with cell lysing buffer (containing $4 \%$ SDS $)$ followed by physical disruption $(2,160 \times g$ for 3 min at room temperature using Biospec Mini Beads Beater 16, BioSpec, Bartlesville, OK). Then, DNA was isolated using $10 \mathrm{M}$ ammonium acetate and precipitated using isopropanol followed by further purification using a QIAmp fast DNA stool mini kit (Qiagen Inc., Germantown, MD). Quantity and purity of the DNA were evaluated using NanoDrop 1000 spectrophotometer (Nanodrop Technologies, Wilmington, DE) and DNA was stored at $-20^{\circ} \mathrm{C}$ until further analysis.

Real-time PCR was used to estimate $16 \mathrm{~S}$ rRNA gene copy numbers of total bacteria; cellulose digesters $R u$ minococcus albus (Zhou et al., 2015), Fecalibacterium prausnitzii (Kopečný et al., 2004), and Fibrobacter succinogenes S85 (Zhou et al., 2015); hemicellulose digesters Butyrivibrio fibrisolvens (Zhou et al., 2015), Ruminococcus flavefaciens (Zhou et al., 2015), and Prevotella sp. (Zhou et al., 2015); and the fiber digester Clostridium cluster IV (Zeng et al., 2015). Primers (Table 2) specific to each bacteria and SYBR Green chemistry (Fast SYBR Green Master Mix, Applied Biosystems, Foster City, CA) were used for PCR. Bacterial populations were estimated using high-throughput Viia 7 Real-Time PCR System (Thermo Fisher Scientific, Waltham, MA). Purified 16S rRNA genes of Butyrivibrio hungatei, R. albus 7, Clostridium cluster IV, B. fibrisolvens, $F$. prausnitzii A2-165, $R$. flavefaciens (ATCC 49949), Prevotella ruminicola (ATCC 19189), and F. succinogenes (ATCC 19189) were used as standards for each bacterial community, respectively.

The copy number of $16 \mathrm{~S}$ rRNA genes per unit of sample for total bacteria and other communities was calculated using the equation as described by $\mathrm{Li}$ et al. (2009): 


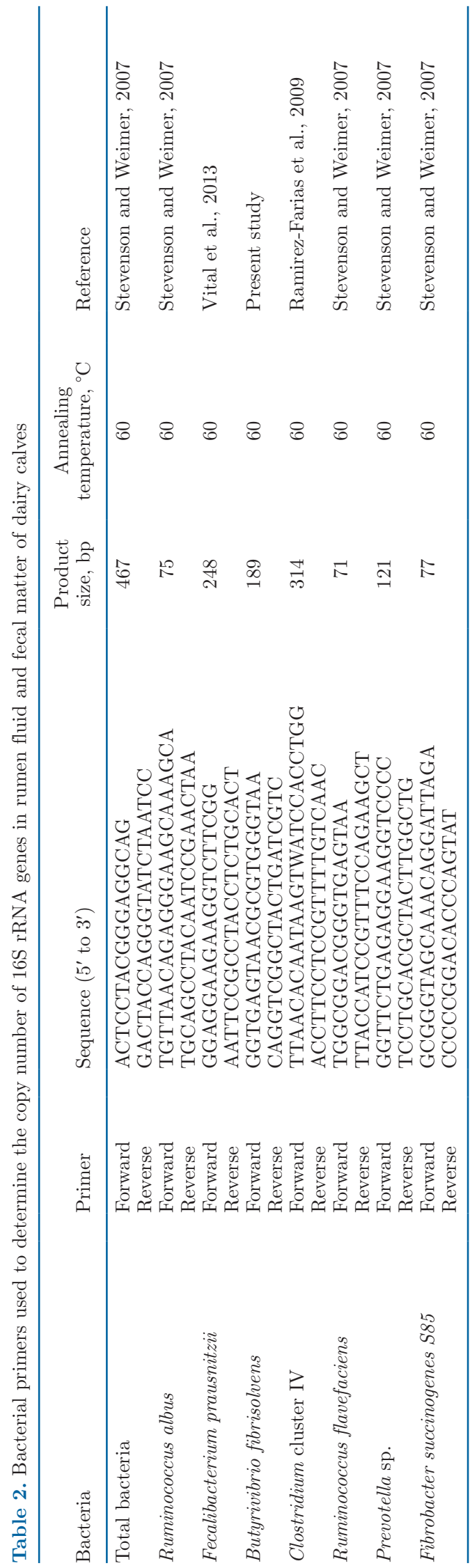

copy number $=$

$\frac{\left[\begin{array}{c}\text { copy number obtained } \\ \times \text { total DNA amount per unit of sample }(\mathrm{ng}) \\ 20 \mathrm{ng}(\text { amount of template used for real-time reaction })\end{array}\right]}{\text { amount of sample used }(\mathrm{g})}$.

Proportion (\% of total bacteria) of each community was also calculated:

$$
\begin{aligned}
& \text { proportion }= \\
& \frac{\text { copy number of a community }}{\text { total bacterial copy number per unit of sample }} \times 100 \text {. }
\end{aligned}
$$

\section{Statistical Analyses}

Data were analyzed as a completely randomized $2 \times$ 2 factorial design using the mixed model procedure of SAS (version 9.4, SAS Institute Inc., Cary, NC). The statistical model used was $\mathrm{Y}=\mu+\mathrm{MR}+\mathrm{CS}+(\mathrm{MR}$ $\times \mathrm{CS})+\mathrm{e}$, where $\mathrm{Y}$ is the dependent variable, $\mu$ is the mean, MR is the effect of MR feeding rate, CS is the effect of corn processing, $\mathrm{MR} \times \mathrm{CS}$ is the interaction of MR and corn processing in CS, and e is the error term. Data collected over time were summarized by week and repeated measures were used. Tukey test was used to separate the least squares means. At least 3 variance-covariance structures (auto-regressive type 1, Toeplitz, and compound symmetry) were tested and the covariance structure that minimized the Schwarz's Bayesian information criterion was chosen. Significance was declared at $P<0.05$ and tendencies at $0.05 \leq P$ $<0.10$.

\section{RESULTS}

\section{Intake, Growth Performance, and Efficiency}

Milk replacer intake was affected by week $\times$ treatment interaction (Figure 1A; $P<0.0001$ ) due to the step-up protocol followed by calves on the HI diet. Calf starter intake, BW, and ADG were influenced by week (Figure 1B, C and D; $P<0.0001$ ). Calves fed HI had greater (Figure 1A; $P<0.001$ ) MR intake at wk 2 to 6 compared with calves fed LO, which led to a $48.6 \%$ increase in total MR intake (Table $3 ; P<0.0001$ ) for calves fed HI compared with calves fed LO. Calves fed HI had $3.6 \mathrm{~kg}$ greater MR refusals than calves fed LO. Calf starter intake was greater at wk 4 to 7 (Figure $1 \mathrm{~B} ; P \leq 0.0005)$ and had a tendency $(P \leq 0.10)$ to be greater at wk 8 in calves fed LO versus HI. Total CS intake was higher (Table $3 ; P \leq 0.0083$ ) during the pre- 
LO-WC
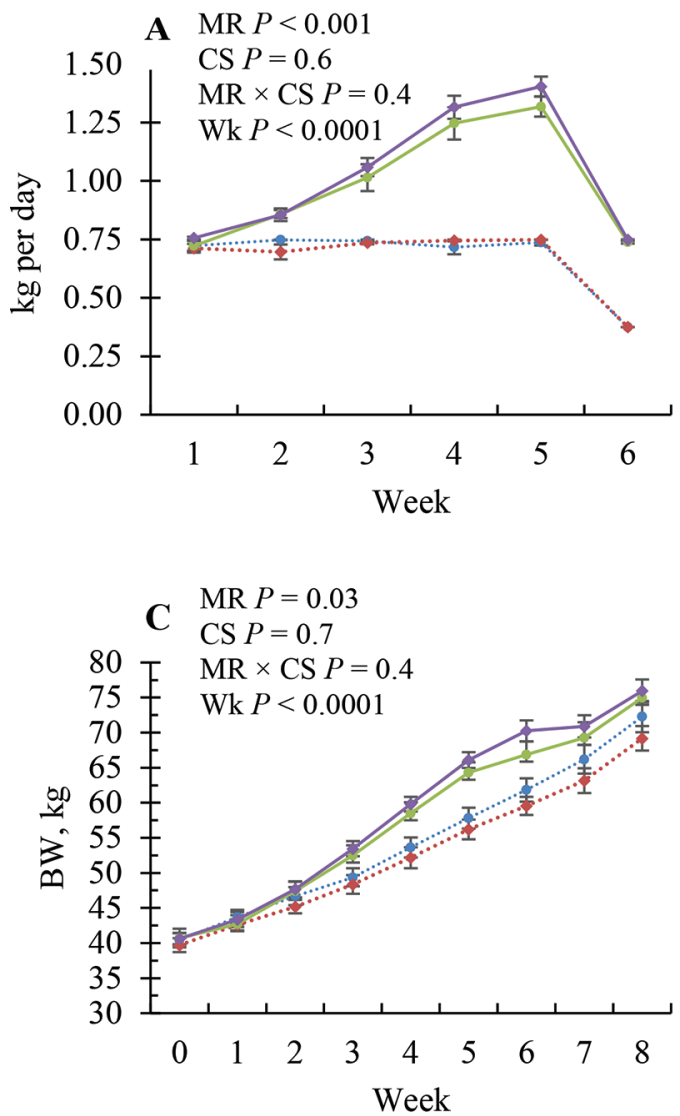

LO-FC HI-WC HI-FC
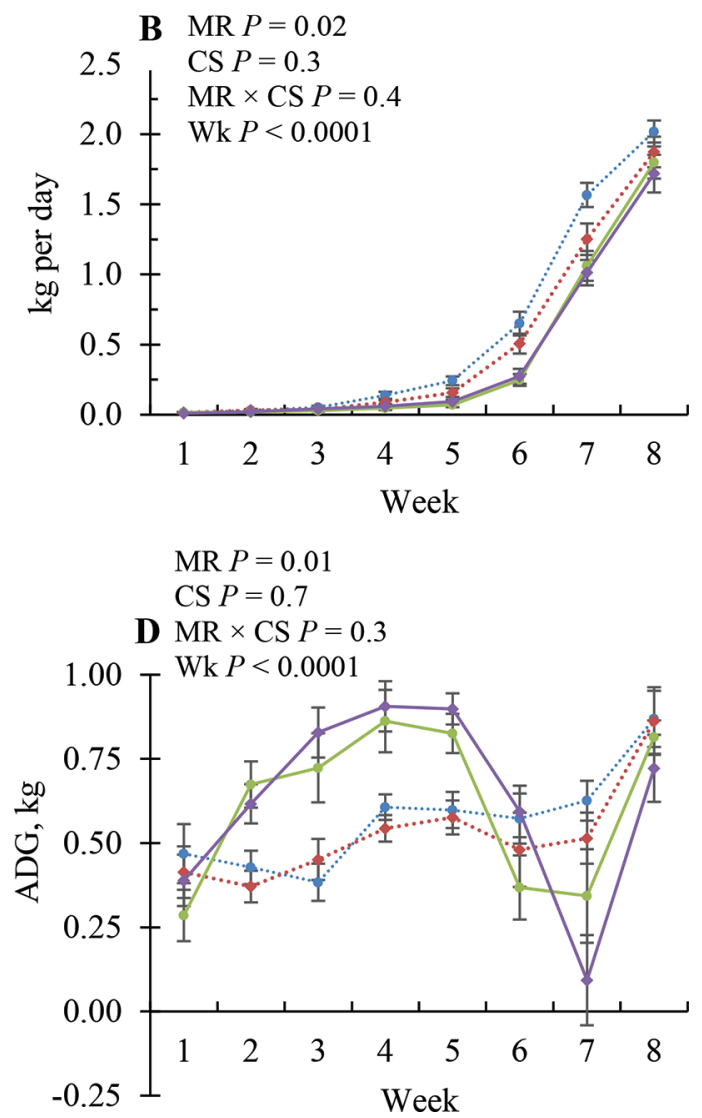

Figure 1. Mean weekly (A) milk replacer (MR) intake, (B) calf starter (CS) intake, (C) BW, and (D) ADG for calves fed a low (LO) or high (HI) MR feeding rate and CS containing whole (WC) or flaked (FC) corn (wk 1 to 8). Milk replacer was fed at $\mathrm{LO}=0.749 \mathrm{~kg} / \mathrm{d}$ of $\mathrm{MR}$ for 35 $\mathrm{d}$, then $0.375 \mathrm{~kg} / \mathrm{d}$ for the last $7 \mathrm{~d}$; HI $=0.749 \mathrm{~kg} / \mathrm{d}$ of MR for $6 \mathrm{~d}, 0.851 \mathrm{~kg} / \mathrm{d}$ for $7 \mathrm{~d}, 1.135 \mathrm{~kg} / \mathrm{d}$ for $7 \mathrm{~d}, 1.498 \mathrm{~kg} / \mathrm{d} \mathrm{for} 15 \mathrm{~d}$, then $0.749 \mathrm{~kg} / \mathrm{d}$ for the last $7 \mathrm{~d}$. Error bars represent SEM for each treatment $\times$ week interaction.

and postweaning period for calves fed LO versus HI, which resulted in total CS intake for the overall period being $33 \%$ greater $(P=0.001)$ for calves fed LO versus HI. Calves fed HI were heavier from wk 3 to 8 compared with calves fed LO (Figure 1C; $P \leq 0.022$ ). Calves fed HI had greater ADG at wk 2, 3, 4, and 5 (Figure 1D; $P=0.01$ ), but lower ADG at wk 7 (the week after weaning) compared with calves fed LO. Body weight gain during the preweaning period was higher (Table 3; $P<0.0001)$ and lower $(P=0.0008)$ during the postweaning period for calves fed HI compared with LO. Overall BW gain for the pre- and postweaning period were higher $(P=0.01)$ in calves fed HI compared with LO. Other initial and wk 8 measurements (BW, hip height and width, and heart and paunch girth) were similar among dietary treatments. Pre- and postweaning and overall (pre- and postweaning period) energy efficiency did not differ among dietary treatments. Milk replacer and CS intake, BW and ADG were unaffected by corn processing in CS (Figure 1). This resulted in no change in total MR and CS intake and performance measurements during the pre- and postweaning and overall (pre- and postweaning) period (Table 3). Also, no effect was observed of the combination of MR feeding rate and corn processing on intake, performance, and efficiency during the pre- and postweaning and overall (pre- and postweaning period) period (Figure 1 and Table 3).

Total DMI was unaffected by dietary treatment during the grower phase (Table 4). Final BW and other body measurements were unaffected by dietary treatment. Calves fed LO had greater $(P<0.0001)$ energy efficiency during the grower phase than calves fed HI, which resulted in LO calves having higher $(P=0.018)$ BW gain during this period. Hip width tended $(P=$ 0.06 ) to be higher for calves fed LO compared with HI. No effect was observed of processing of corn or the combination of MR feeding rate and corn processing 
Table 3. Effect of treatment ${ }^{1}$ on intake, growth performance, and efficiency in dairy calves (0 to 8 wk)

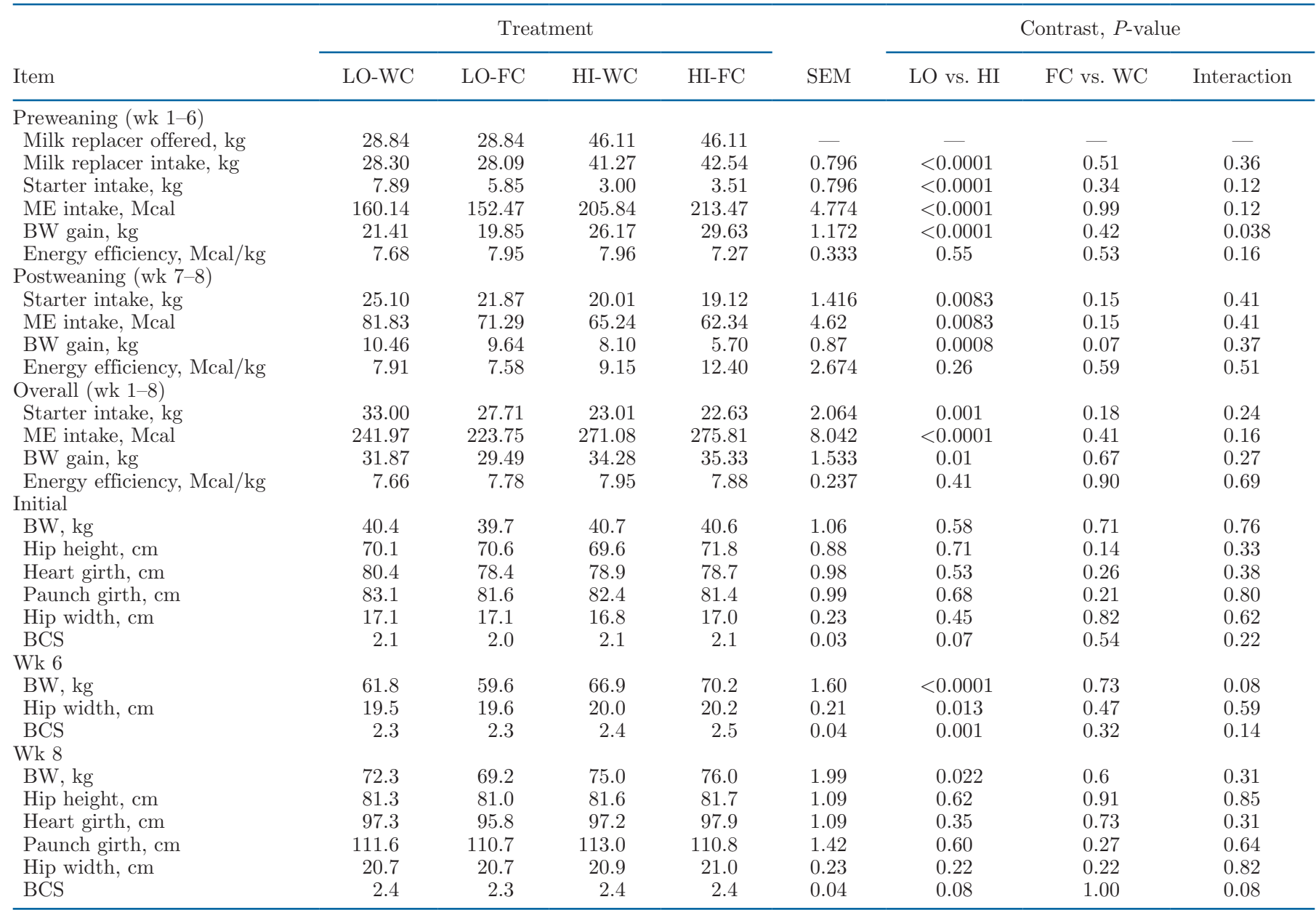

${ }^{1}$ Treatment: $\mathrm{LO}=0.749 \mathrm{~kg} / \mathrm{d}$ of milk replacer $(\mathrm{MR})$ for $35 \mathrm{~d}$, then $0.375 \mathrm{~kg} / \mathrm{d}$ for the last $7 \mathrm{~d}$; $\mathrm{HI}=0.749 \mathrm{~kg} / \mathrm{d}$ of $\mathrm{MR}$ for $6 \mathrm{~d}, 0.851 \mathrm{~kg} / \mathrm{d}$ for $7 \mathrm{~d}$, $1.135 \mathrm{~kg} / \mathrm{d}$ for $7 \mathrm{~d}, 1.498 \mathrm{~kg} / \mathrm{d}$ for $15 \mathrm{~d}$, then $0.749 \mathrm{~kg} / \mathrm{d}$ for the last $7 \mathrm{~d}$; WC $=$ whole corn and $\mathrm{FC}=$ steam-flaked corn in textured calf starter.

Table 4. Effect of treatment ${ }^{1}$ on intake, growth performance, and efficiency from wk 9 to 16 in dairy calves

\begin{tabular}{|c|c|c|c|c|c|c|c|c|}
\hline Item & \multicolumn{4}{|c|}{ Treatment } & SEM & \multicolumn{3}{|c|}{ Contrast, $P$-value } \\
\hline DMI, kg & 173.71 & 159.64 & 163.39 & 162.71 & 8.340 & 0.68 & 0.40 & 0.45 \\
\hline ME intake, Mcal & 555.87 & 510.86 & 522.85 & 520.66 & 26.689 & 0.68 & 0.40 & 0.45 \\
\hline $\mathrm{BW}$ gain, kg & 61.37 & 60.18 & 52.21 & 52.69 & 1.067 & $<0.0001$ & 0.75 & 0.46 \\
\hline Energy efficiency, Mcal/kg & 9.01 & 8.48 & 10.02 & 9.87 & 0.401 & 0.018 & 0.39 & 0.61 \\
\hline Hip height, cm & 92.7 & 91.9 & 92.3 & 91.9 & 1.04 & 0.84 & 0.55 & 0.87 \\
\hline Heart girth, cm & 116.6 & 113.8 & 114.5 & 115.5 & 1.43 & 0.91 & 0.53 & 0.19 \\
\hline Paunch girth, cm & 145.9 & 142.0 & 144.0 & 143.3 & 1.72 & 0.87 & 0.19 & 0.35 \\
\hline Hip width, cm & 25.9 & 25.4 & 25.1 & 25.3 & 0.24 & 0.06 & 0.73 & 0.15 \\
\hline BCS & 2.7 & 2.6 & 2.6 & 2.7 & 0.08 & 1.00 & 1.00 & 0.59 \\
\hline
\end{tabular}

${ }^{1}$ Treatment: $\mathrm{LO}=0.749 \mathrm{~kg} / \mathrm{d}$ of milk replacer $(\mathrm{MR})$ for $35 \mathrm{~d}$, then $0.375 \mathrm{~kg} / \mathrm{d}$ for the last $7 \mathrm{~d}$; $\mathrm{HI}=0.749 \mathrm{~kg} / \mathrm{d}$ of $\mathrm{MR}$ for $6 \mathrm{~d}, 0.851 \mathrm{~kg} / \mathrm{d}$ for $7 \mathrm{~d}$, $1.135 \mathrm{~kg} / \mathrm{d}$ for $7 \mathrm{~d}, 1.498 \mathrm{~kg} / \mathrm{d}$ for $15 \mathrm{~d}$, then $0.749 \mathrm{~kg} / \mathrm{d}$ for the last $7 \mathrm{~d}$; WC $=$ whole corn and $\mathrm{FC}=$ steam-flaked corn in textured calf starter. 
Table 5. Effect of treatment ${ }^{1}$ on apparent total-tract digestibility during 3 different time points (wk 5, 8, and 12) in dairy calves

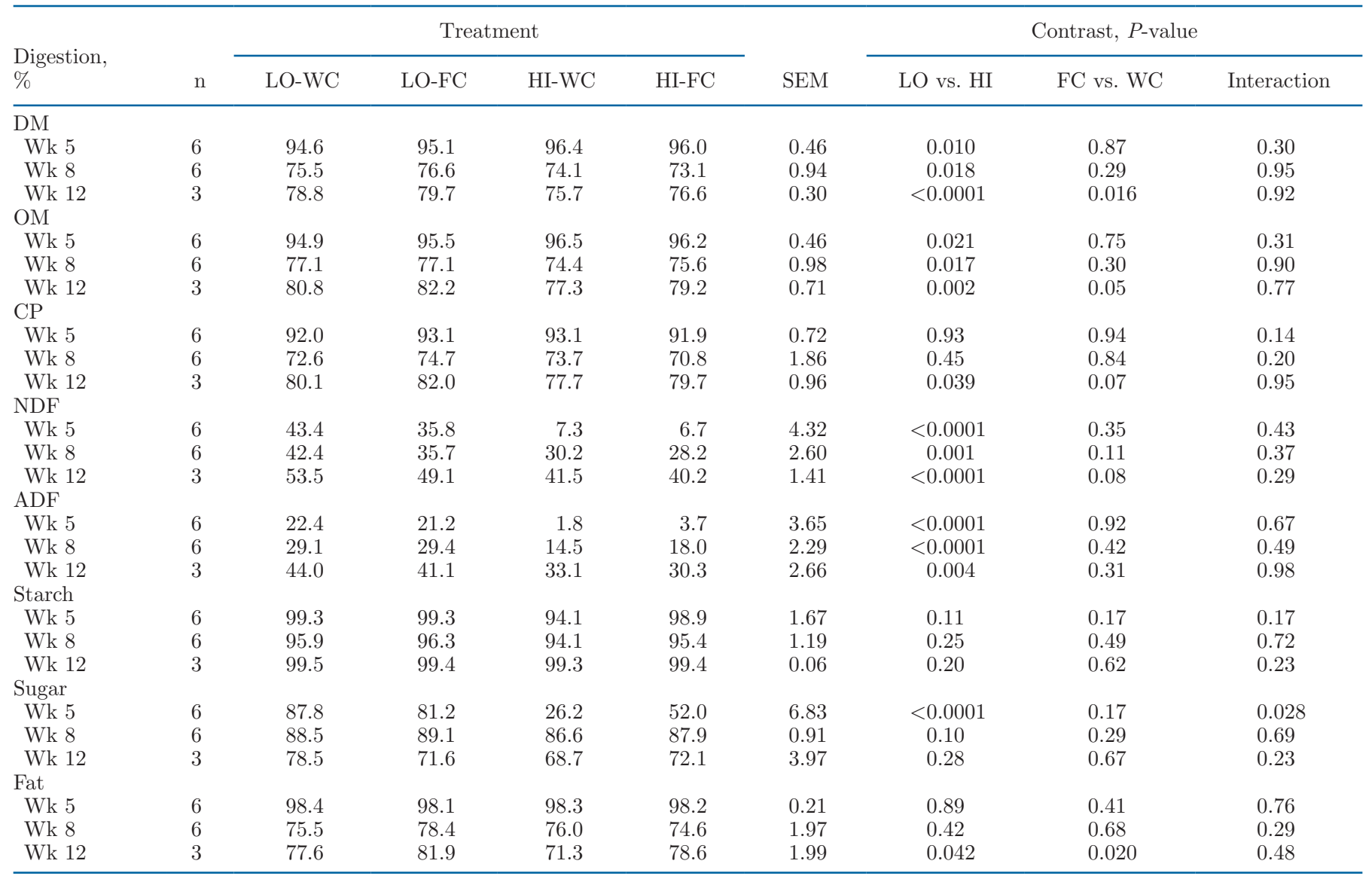

${ }^{1}$ Treatment: $\mathrm{LO}=0.749 \mathrm{~kg} / \mathrm{d}$ of milk replacer $(\mathrm{MR})$ for $35 \mathrm{~d}$, then $0.375 \mathrm{~kg} / \mathrm{d}$ for the last $7 \mathrm{~d}$; $\mathrm{HI}=0.749 \mathrm{~kg} / \mathrm{d}$ of $\mathrm{MR}$ for $6 \mathrm{~d}$, $0.851 \mathrm{~kg} / \mathrm{d}$ for $7 \mathrm{~d}$, $1.135 \mathrm{~kg} / \mathrm{d}$ for $7 \mathrm{~d}, 1.498 \mathrm{~kg} / \mathrm{d}$ for $15 \mathrm{~d}$, then $0.749 \mathrm{~kg} / \mathrm{d}$ for the last $7 \mathrm{~d}$; WC = whole corn and $\mathrm{FC}=$ steam-flaked corn in textured calf starter.

on intake, performance, or efficiency during the grower phase.

\section{Apparent Total-Tract Nutrient Digestibility}

Digestibility of DM and OM was lower $(P \leq 0.02)$ in calves fed LO compared with HI during wk 5 , but during wk 8 and 12 calves fed LO had higher $(P \leq 0.02)$ $\mathrm{DM}$ and $\mathrm{OM}$ digestibility compared with calves fed HI (Table 5). Calves fed FC had higher $(P \leq 0.05)$ DM, $\mathrm{OM}$, and fat digestibility and tended to have higher $(P$ $=0.07) \mathrm{CP}$ digestibility and lower $(P=0.08) \mathrm{NDF}$ digestibility during wk 12 compared with calves fed WC. Calves fed LO had higher $(P=0.039)$ CP digestibility during wk 12 compared with calves fed HI. During wk 5,8 , and 12, calves fed LO had 5.6-, 1.3-, and 1.3fold higher $(P \leq 0.001)$ NDF digestibility, respectively, compared with calves fed HI. Digestibility of ADF had a similar pattern to NDF, where calves fed LO had 7.9-, 1.8-, and 1.3-fold higher $(P \leq 0.004)$ digestibility for wk 5,8 , and 12 , respectively, compared with calves fed
HI. An interaction was observed between MR level and processing of corn in CS for sugar digestibility during wk 5. Calves fed HI-WC had the lowest $(P=0.028)$ digestibility. Calves fed LO tended to have higher $(P$ $=0.10)$ sugar digestibility during wk 5 and higher $(P$ $=0.042)$ fat digestibility during wk 12 compared with calves fed HI.

\section{Fibrolytic Bacteria Quantification}

Density of total bacteria and fibrolytic bacterial community in rumen fluid were unaffected by dietary treatment at wk 5 and 8 (Table 6 ). No effect was observed for ruminal total bacteria at wk 5 and 8 . At wk 5, B. fibrisolvens density tended to be higher $(P=$ $0.05)$ in calves fed LO compared with HI. Proportion (\% of total bacteria) of Clostridium cluster IV and $B$. fibrisolvens tended $(P \leq 0.07)$ to be 2 -fold higher in rumen fluid when calves were fed LO compared with $\mathrm{HI}$ at wk 5. At wk 8, proportion of Ruminococcus albus was higher $(P=0.045)$ in rumen fluid of calves fed 
LO-WC compared with calves fed LO-FC and HI-WC. In fecal matter, total bacteria was unaffected by diet at wk 5 and 8 (Table 7). Clostridium cluster IV, Fecalibacterium sp., and Prevotella sp. densities were higher $(P \leq 0.003)$ and $B$. fibrisolvens density tended to be higher $(P=0.09)$ in calves fed LO compared with HI at wk 5. Fecalibacterium sp. density also tended to be higher $(P=0.07)$ at wk 8 in calves fed LO compared with HI. In contrast, $R$. flavefaciens density was higher $(P<0.0001)$ in calves fed HI compared with LO during wk 5. At wk 5, proportions of Clostridium cluster IV, Fecalibacterium sp., and Prevotella sp. were higher $(P$ $\leq 0.043)$ and $R$. flavefaciens tended to be lower $(P=$ 0.05 ) in calves fed LO compared with HI. No dietary treatment effects were observed on proportion of any bacterial community at wk 8 .

\section{DISCUSSION}

The goal of this study was to determine the effect of amount of MR fed and the processing method of corn in CS on calf performance, digestibility, and rumen and fecal bacterial communities. Based on our findings, MR treatment had a greater effect on performance, fiber digestibility, and rumen and fecal fibrolytic bacterial communities in dairy calves than corn processing in CS treatment.

\section{Effect of MR Feeding Rate}

Similar findings to the present study regarding MR feeding rate (LO vs. HI) and its effect on preweaning CS intake (Hill et al., 2016a; Dennis et al., 2018, 2019), BW (Jasper and Weary, 2002; Khan et al., 2011; Rosenberger et al., 2017) and fiber apparent totaltract digestibility (Hill et al., 2016a; Dennis et al., 2018) have been reported. Feeding high rates of MR to calves should provide enough nutrients to sustain satiety largely on MR alone, thus decreasing CS intake compared with calves fed MR at a low rate, as was shown in the present study and previous reports (Hill et al., 2016a; Dennis et al., 2018, 2019). The higher rate of MR feeding also resulted in higher BW until wk 7 from the greater ME intake compared with calves fed MR at a lower rate (Rosenberger et al., 2017). In addition, MR has a higher digestibility compared with CS, therefore contributing more energy toward growth compared with CS. Studies reporting NDF and ADF digestibility have consistently noted that calves fed higher rates of MR have lower NDF and ADF digestibility at various weeks of life (Chapman et al., 2016; Dennis et al., 2018, 2019). In our study, poor fiber apparent total-tract digestibility was carried over into the grower period (6 wk after weaning) by calves fed HI, as reported previously (Hill et al., 2016a). This was thought to be indicative of inadequate rumen microbial fermentation due to reduced CS intake when calves are fed a high MR feeding rate preweaning (Hill et al., 2016a). Calves fed LO tended to have increased $B$. fibrisolvens density and B. fibrisolvens and Clostridium cluster IV proportions during wk 5 in the rumen, possibly from the increase in CS intake, which may support greater fiber digestion observed in LO versus HI calves. The proportion of Clostridium cluster IV and Fecalibacterium sp. increased in the fecal matter of LO calves at wk 5 , which suggests that more fiber digestion may occur in the hindgut of calves fed LO versus HI. The extent and biological significance of fiber digestion postruminally in calves is largely unknown; however, Gressley et al. (2011) summarized a variety of studies from mature ruminants and reported that NDF digestion can range from 3.7 to $23.2 \%$ and $\mathrm{ADF}$ digestion from 3.3 to $6.5 \%$ in the large intestine. In the present study, only a select number of fibrolytic bacteria were identified using quantitative PCR and their activity was not evaluated. Few differences were observed regarding the effect of MR treatment on the proportion of bacteria. We postulate that this may be due to the high variation (CV range: 10.0 to $240.7 \%$ in rumen fluid, 40.3 to $214.1 \%$ in fecal matter) between calves within the same dietary treatment for the proportion of fibrolytic bacterial communities.

Different dietary sources (MR vs. CS) have different digestibilities and the ratio of MR to CS intake in calves differed at wk 5 , which resulted in calves fed HI having higher DM and OM digestibility compared with calves fed LO. Digestibility of DM and OM may influence intake and calves fed LO had higher DM and OM digestibility when only consuming solid feed, as well as higher CS intake postweaning. However, during the grower phase, intakes were unaffected by dietary treatment.

Calves fed LO tended to have a higher proportion of ruminal fibrolytic bacteria (B. fibrisolvens and Clostridium cluster IV) and a higher proportion of fecal fibrolytic bacteria (Fecalibacterium sp., Clostridium cluster IV, and Prevotella sp.) than calves fed HI during wk 5. Additionally, calves fed LO had greater digestion of $\mathrm{OM}$ and fiber than calves fed HI. Greater growth rates in both $\mathrm{BW}$ and structure during wk 9 to 16 for calves fed LO versus HI was likely attributed to better development of the digestive system and transition to a dry feed diet. These digestibility and performance measures are consistent with several other studies (Hill et al., 2016a; Dennis et al., 2018). The CS in the present study contained a high amount of starch (41.5\%), with $\mathrm{ADF}$ and NDF being low at 7.2 and $15.4 \%$, re- 
van Niekerk et al.: RATE OF MILK AND CORN PROCESSING IN CALVES

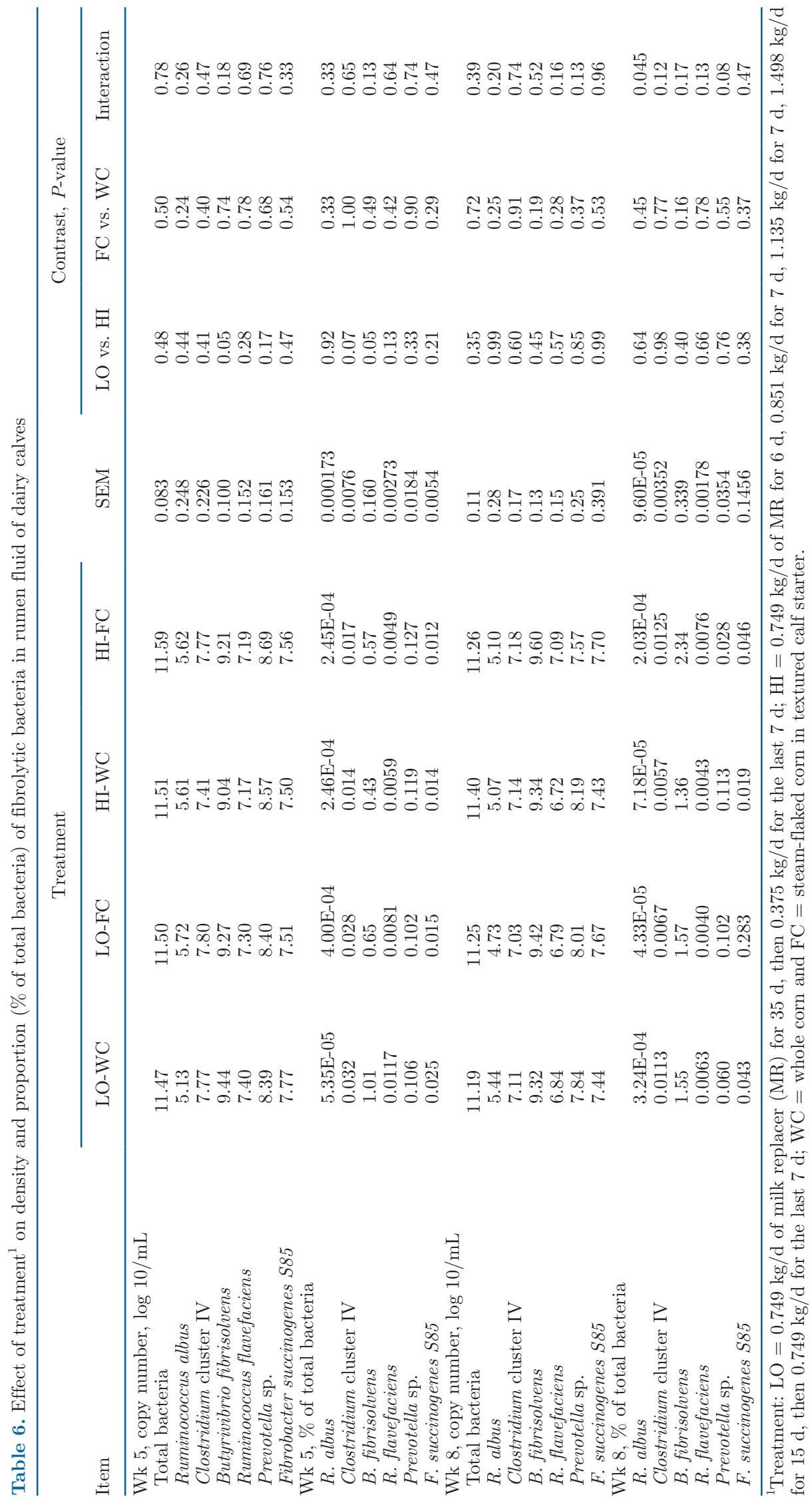


van Niekerk et al.: RATE OF MILK AND CORN PROCESSING IN CALVES

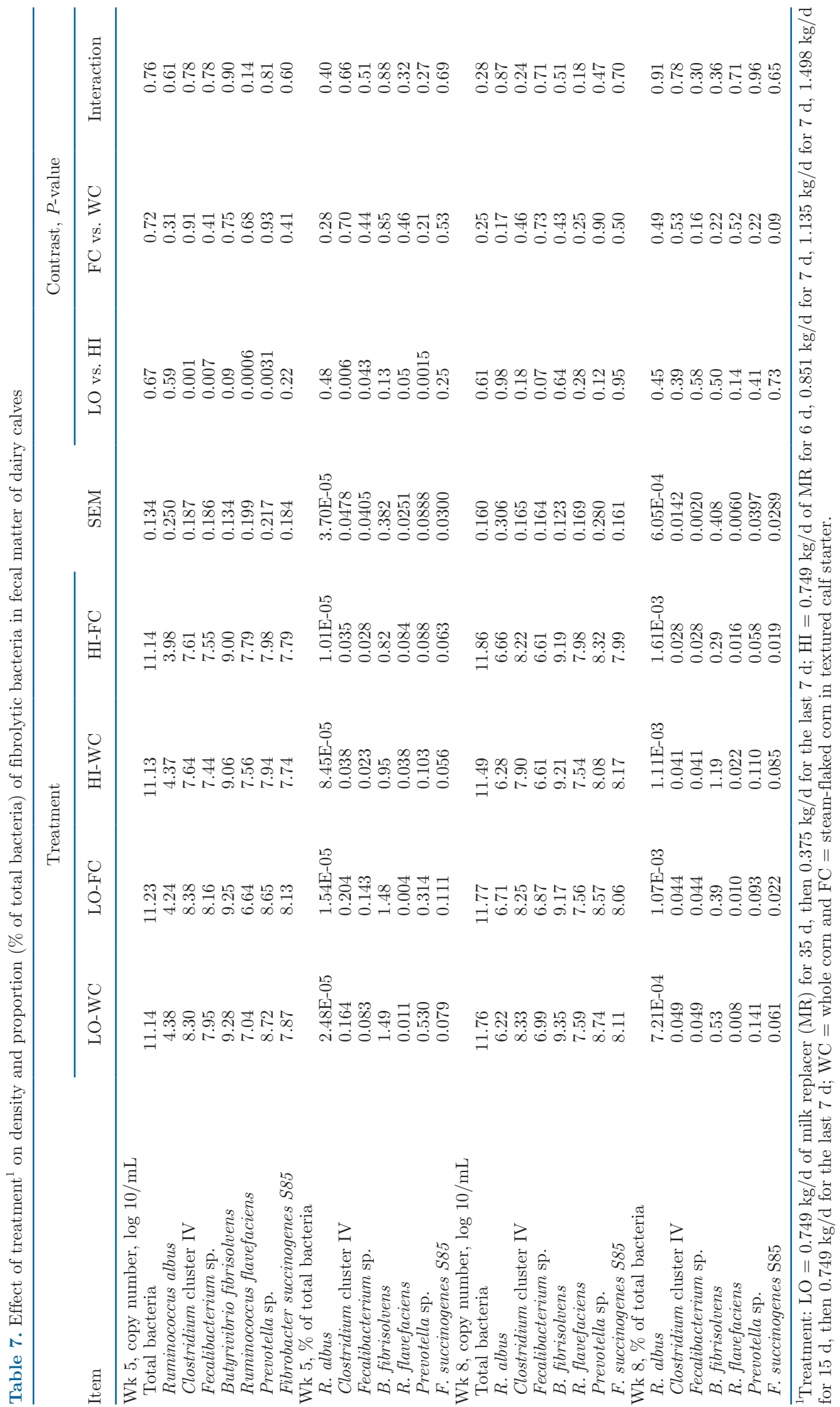


spectively; therefore, additional factors contributing to fiber digestion may play a role and resulted in a growth depression. It is possible that HI calves, when weaned at wk 6 with a 1 -wk step-down, experience greater gut health challenges during the weeks postweaning, causing more energy to be partitioned to the gut to adapt and recover from the more dramatic weaning transition (Steele et al., 2016).

Overall, the poor DM, OM, and fiber digestibility observed in our study during the postweaning stage for calves fed the HI diet resulted in fewer nutrients available for utilization toward growth. During the grower phase, calves fed the LO diet were more efficient at utilizing feed, resulting in calves fed the HI diet to lose their preweaning growth advantage by wk 16. However, it is important to note that these calves were bedded with long wheat straw and consumption was not accounted for. Yet, Hill et al. (2019) reported that digestion estimates were not affected when calves were bedded on long straw compared with no straw. Thus, we speculate that bedding consumption would have had minimal effect in the current study.

\section{Effect of Corn Processing}

Processing grain can maximize starch digestibility, yet processing can also change the site of digestion (Owens, 2005). Processing corn may be beneficial to young calves because starch digestion in the rumen stimulates rumen papillae development (Flatt et al., 1958; Sander et al., 1959). Based on unpublished data, dietary treatment had no influence $(P \geq 0.12)$ on total ruminal short-chain fatty acid (SCFA) concentration during wk 5 or 8 , which may indicate that corn was fermented to the same extent in the rumen in both treatments. The SCFA concentration did increase from wk 5 to 8 , which is reflective of increased starter intake. The total SCFA averages were as follows: $47.3 \pm 8.3$, $36.9 \pm 5.7,31.4 \pm 1.1$, and $36.8 \pm 6.4 \mu \mathrm{mol} / \mathrm{mL}$ for LOWC, HI-FC, HI-WC, and HI-FC, respectively, during wk 5 , and $62.6 \pm 6.0,62.5 \pm 6.3,61.5 \pm 4.2$, and $72.5 \pm$ $8.3 \mu \mathrm{mol} / \mathrm{mL}$ for LO-WC, HI-FC, HI-WC, and HI-FC, respectively, during wk 8 . It has been demonstrated that total-tract digestibility of steam-rolled (or flaked) corn was $97 \%$ compared with $84 \%$ for whole corn in mature ruminants (Owens, 2005). Thus, starch digestibility in the current study was expected to be different among CS treatments based on mature ruminant data; however, no differences were observed ( $>95 \%$ for both treatments wk 5, 8, and 12). Owens (2005) reported that site and extent of digestion and passage rate of corn (whole or processed) can be altered by dietary fiber levels in the diet. We speculate that the low levels of fiber in our diet compared with feedlot or lactating cow diets may have resulted in equal digestion between CS treatments. It is possible that passage rate of corn is different in calves than that of adult animals because of different particle distribution in the rumen and calves may also have the ability to use whole corn kernels more efficiently than cows by chewing their feed more thoroughly (Owens, 2005), which would affect starch digestion. Thus, further investigation into corn processing and digestion when forage is included in the diet preweaning is warranted. Specifically, future research should investigate rumination times in young calves fed differentially processed corn to provide further insight into the mechanisms responsible for the comparable digestion of whole corn and steam-flaked corn evidenced in the present study.

Calves fed WC had decreased DM and OM digestibility during wk 12 compared with calves fed FC, but this result is most likely due to the observed lower CP and fat digestion in $\mathrm{WC}$ calves. Consistent with previous studies (preweaning: Lesmeister and Heinrichs, 2004; pre- and postweaning: Bateman et al., 2009), the processing of corn in CS did not influence intake and, thus, calf performance. In contrast, previous studies have shown that CS intake increased when whole corn was fed to calves compared with steam-flaked (postweaning: Lesmeister and Heinrichs, 2004) and steam-rolled (during weaning: Terré et al., 2016) corn. Although digestibility was not measured in these studies, the increase in CS intake did not result in increased BW, suggesting that calves were unable to use the additional nutrients toward growth. Lesmeister and Heinrichs (2004) reported that total SCFA concentrations were lower in the whole corn-fed calves compared with the steam-flaked-corn-fed calves, indicating that whole corn was not digested in the rumen to the same extent as steam-flaked, and that a certain amount must have bypassed the rumen. Starch digestion in the rumen is beneficial for ruminal development and thus further investigation on site of digestion of whole corn in calves is warranted, especially given the high cost of corn processing. All of the above-mentioned studies (Lesmeister and Heinrichs, 2004; Bateman et al., 2009; Terré et al., 2016) only investigated the effects of grain processing when calves were fed a low MR feeding rate $(<6 \mathrm{~L})$, and therefore the interaction with higher MR feeding rate is unknown.

\section{Interaction of MR Feeding Rate with Processing of Corn in CS}

The effect of milk/MR feeding rate on intake, growth performance, and total-tract nutrient digestibility has 
been investigated in numerous studies (Terré et al., 2007; Hill et al., 2010, 2016a; Chapman et al., 2016) in relation to weaning method/age (Dennis et al., 2018), amount of starch in CS (Quigley et al., 2018), and additives (Hill et al., 2016b; Dennis et al., 2018), but not in relation to the processing of corn in CS. To our knowledge, this is the first study to evaluate the combination of MR feeding rate with processing of corn in CS (whole vs. steam-flaked corn) in calves. We thought that feeding a higher rate of MR would delay rumen development and WC-fed calves would have reduced nutrient digestibility. When digestibility is reduced, and CS intake remains the same between the WC and FC, calf performance would be reduced. However, we found that the combination of MR feeding rate and corn processing in CS did not have an effect on digestibility, as hypothesized, although CS intakes were similar between the WC and FC. However, during wk 5, sugar digestibility was lower for calves fed the HIWC diet compared with the other dietary treatments, which could have resulted in numerically lower starch digestion for this treatment. As expected, BW, ADG, body measurements, and feed efficiency throughout the study were not affected by dietary treatment, since no change was observed in CS intake or digestibility. As described above, fiber content in the diet could influence corn digestibility, yet minimal amounts of fiber were included in these diets. Therefore, the addition of fiber or low starch diets on the digestibility of corn in calves fed high rates of MR needs to be explored further.

\section{CONCLUSIONS}

Our results show that a high MR feeding rate reduced fiber digestibility, both pre- and postweaning and during the grower phase (wk 5, 8, and 12). Preweaning ADG and hip width measurements were higher in $\mathrm{HI}$ versus LO MR feeding rate, but reduced postweaning, resulting in similar BW and hip width measurements by 16 wk of age. Calves fed LO had a higher proportion of fibrolytic bacteria in both the rumen and feces than calves fed HI. When considering the combination of MR feeding rate and the processing of corn feeding, low and high MR feeding rate can be combined with either flaked corn or whole corn in the CS because corn processing had little to no effect on digestibility, intake, and growth of calves.

\section{ACKNOWLEDGMENTS}

The authors thank Provimi North America, a division of Cargill Animal Nutrition, Mitacs, Natural Sciences and Engineering Research Council of Canada, Alberta Milk (Edmonton, AB, Canada), Lallemand (Montreal, QC, Canada), Westgen (Abbotsford, BC, Canada), BC Dairy Association (Burnaby, BC, Canada), SaskMilk (Regina, SK, Canada), and the Dairy Farmers of Manitoba (Winnipeg, MB, Canada) for the financial support provided for this study. The authors also thank the Provimi staff for their help with calf management and care, M. Erickson (Purdue University) for sampling and Y. Chen for assistance with laboratory analysis. The authors have not stated any conflicts of interest.

\section{REFERENCES}

AOAC International. 2000. Official Methods of Analysis. Vol. I. 17th ed. AOAC International, Arlington, VA.

Bateman, H. G., II, T. M. Hill, J. M. Aldrich, and R. L. Schlotterbeck. 2009. Effects of corn processing, particle size, and diet form on performance of calves in bedded pens. J. Dairy Sci. 92:782-789. https://doi.org/10.3168/jds.2008-1242.

CCAC. 1993. Guide to the Care and Use of Experimental Animals. Vol. 1. E. D. Olfert, B. M. Cross, and A. A. McWilliams, ed. Canadian Council on Animal Care, Ottawa, ON, Canada.

Chapman, C. E., P. S. Erickson, J. D. Quigley, T. M. Hill, H. G. Bateman II, F. X. Suarez-Mena, and R. L. Schlotterbeck. 2016. Effect of milk replacer program on calf performance and digestion of nutrients with age of the dairy calf. J. Dairy Sci. 99:2740-2747. https://doi.org/10.3168/jds.2015-10372.

Cowles, K. E., R. A. White, N. L. Whitehouse, and P. S. Erickson. 2006. Growth characteristics of calves fed an intensified milk replacer regimen with additional lactoferrin. J. Dairy Sci. 89:48354845. https://doi.org/10.3168/jds.S0022-0302(06)72532-2.

Davis Rincker, L. E., M. J. VandeHaar, C. A. Wolf, J. S. Liesman, L. T. Chapin, and M. S. Weber Nielsen. 2011. Effect of intensified feeding of heifer calves on growth, pubertal age, calving age, milk yield, and economics. J. Dairy Sci. 94:3554-3567. https://doi.org/ 10.3168/jds.2010-3923.

Dennis, T. S., F. X. Suarez-Mena, T. M. Hill, J. D. Quigley, R. L. Schlotterbeck, and L. Hulbert. 2018. Effect of milk replacer feeding rate, age at weaning, and method of reducing milk replacer to weaning on digestion, performance, rumination, and activity in dairy calves to 4 months of age. J. Dairy Sci. 101:268-278. https:/ /doi.org/10.3168/jds.2017-13692.

Dennis, T. S., F. X. Suarez-Mena, W. Hu, T. M. Hill, J. D. Quigley, and R. L. Schlotterbeck. 2019. Effects of milk replacer feeding rate and long-term antibiotic inclusion in milk replacer on performance and nutrient digestibility of holstein dairy calves up to 4 months of age. J. Dairy Sci. 102:2094-2102. https://doi.org/10.3168/jds .2018-15652.

DuBois, M., K. A. Gilles, J. K. Hamilton, P. A. Rebers, and F. Smith. 1956. Colorimetric method for determination of sugars and related substances. Anal. Chem. 28:350-356. https://doi.org/10.1021/ ac60111a017.

FASS. 1999. Guide for the Care and Use of Agricultural Animals in Agricultural Research and Teaching. 1st rev. ed. FASS, Champaign, IL.

Firkins, J. L., M. L. Eastridge, N. R. St-Pierre, and S. M. Noftsger. 2001. Effects of grain variability and processing on starch utilization by lactating dairy cattle. J. Anim. Sci. 79(E-Suppl):E218. https://doi.org/10.2527/jas2001.79E-SupplE218x.

Flatt, W. P., R. G. Warner, and J. K. Loosli. 1958. Influence of purified materials on the development of the ruminant stomach. J. Dairy Sci. 41:1593-1600. https://doi.org/10.3168/jds.S0022 -0302(58)91138-X.

Geishauser, T. 1993. An instrument for collection and transfer of ruminal fluid and for administration of water soluble drugs in adult cattle. Bovine Practitioner 27:38. 
Gelsinger, S. L., A. J. Heinrichs, and C. M. Jones. 2016. A metaanalysis of the effects of preweaned calf nutrition and growth on first-lactation performance. J. Dairy Sci. 99:6206-6214. https:// doi.org/10.3168/jds.2015-10744.

Gressley, T. F., M. B. Hall, and L. E. Armentano. 2011. Ruminant nutrition symposium: Productivity, digestion, and health responses to hindgut acidosis in ruminants. J. Anim. Sci. 89:1120-1130. https://doi.org/10.2527/jas.2010-3460.

Hall, M. B. 2009. Analysis of starch, including maltooligosaccharides, in animal feeds: A comparison of methods and a method recommended for AOAC collaborative study. J. AOAC Int. 92:42-49.

Hill, T. M., J. M. Aldrich, R. L. Schlotterbeck, and H. G. Bateman II. 2006. Effects of feeding calves different rates and protein concentrations of twenty percent fat milk replacers on growth during the neonatal period. Prof. Anim. Sci. 22:252-260. https://doi.org/10 .15232/S1080-7446(15)31101-3.

Hill, T. M., H. G. Bateman II, J. M. Aldrich, and R. L. Schlotterbeck. 2009. Optimizing nutrient ratios in milk replacers for calves less than five weeks of age. J. Dairy Sci. 92:3281-3291. https://doi.org/ 10.3168/jds.2008-1750.

Hill, T. M., H. G. Bateman II, J. M. Aldrich, and R. L. Schlotterbeck. 2010. Effect of milk replacer program on digestion of nutrients in dairy calves. J. Dairy Sci. 93:1105-1115. https://doi.org/10.3168/ jds.2009-2458.

Hill, T. M., T. S. Dennis, F. X. Suarez-Mena, J. D. Quigley, K. M. Aragona, and R. L. Schlotterbeck. 2019. Effects of free-choice hay and straw bedding on digestion of nutrients in 7-week-old Holstein calves. Appl. Anim. Sci. 35:312-317. https://doi.org/10.15232/aas 2019-01855.

Hill, T. M., J. D. Quigley, H. G. Bateman II, F. X. Suarez-Mena, T. S. Dennis, and R. L. Schlotterbeck. 2016a. Effect of milk replacer program on calf performance and digestion of nutrients in dairy calves to 4 months of age. J. Dairy Sci. 99:8103-8110. https://doi .org/10.3168/jds.2016-11239.

Hill, T. M., J. D. Quigley, F. X. Suarez-Mena, H. G. Bateman II, and R. L. Schlotterbeck. 2016b. Effect of milk replacer feeding rate and functional fatty acids on dairy calf performance and digestion of nutrients. J. Dairy Sci. 99:6352-6361. https://doi.org/10.3168/ jds.2015-10812.

Huntington, G. B. 1997. Starch utilization by ruminants: From basics to the bunk. J. Anim. Sci. 75:852-867. https://doi.org/10.2527/ 1997.753852x.

Jasper, J., and D. M. Weary. 2002. Effects of ad libitum milk intake on dairy calves. J. Dairy Sci. 85:3054-3058. https://doi.org/10.3168/ jds.S0022-0302(02)74391-9.

Jensen, M. B. 2006. Computer-controlled milk feeding of group-housed calves: The effect of milk allowance and weaning type. J. Dairy Sci. 89:201-206. https://doi.org/10.3168/jds.S0022-0302(06)72084-7.

Khan, M. A., A. Bach, D. M. Weary, and M. A. G. von Keyserlingk. 2016. Invited review: Transitioning from milk to solid feed in dairy heifers. J. Dairy Sci. 99:885-902. https://doi.org/10.3168/jds.2015 $-9975$.

Khan, M. A., H. J. Lee, W. S. Lee, H. S. Kim, S. B. Kim, K. S. Ki, J. K. Ha, H. G. Lee, and Y. J. Choi. 2007a. Pre- and postweaning performance of Holstein female calves fed milk through step-down and conventional methods. J. Dairy Sci. 90:876-885. https://doi .org/10.3168/jds.S0022-0302(07)71571-0.

Khan, M. A., H. J. Lee, W. S. Lee, H. S. Kim, S. B. Kim, K. S. Ki, S. J. Park, J. K. Ha, and Y. J. Choi. 2007b. Starch source evaluation in calf starter: I. Feed consumption, body weight gain, structural growth, and blood metabolites in Holstein calves. J. Dairy Sci. 90:5259-5268. https://doi.org/10.3168/jds.2007-0338.

Khan, M. A., D. M. Weary, and M. Von Keyserlingk. 2011. Invited review: Effects of milk ration on solid feed intake, weaning, and performance in dairy heifers. J. Dairy Sci. 94:1071-1081. https:// doi.org/10.3168/jds.2010-3733.

Kopečný, J., J. Hajer, and J. Mrázek. 2004. Detection of cellulolytic bacteria from the human colon. Folia Microbiol. (Praha) 49:175177. https://doi.org/10.1007/BF02931396.

Kristensen, N. B., J. Sehested, S. K. Jensen, and M. Vestergaard. 2007. Effect of milk allowance on concentrate intake, ruminal en- vironment, and ruminal development in milk-fed Holstein calves. J. Dairy Sci. 90:4346-4355. https://doi.org/10.3168/jds.2006-885.

Lesmeister, K. E., and A. J. Heinrichs. 2004. Effects of corn processing on growth characteristics, rumen development, and rumen parameters in neonatal dairy calves. J. Dairy Sci. 87:3439-3450. https:// doi.org/10.3168/jds.S0022-0302(04)73479-7.

Li, M., G. B. Penner, E. Hernandez-Sanabria, M. Oba, and L. L. Guan. 2009. Effects of sampling location and time, and host animal on assessment of bacterial diversity and fermentation parameters in the bovine rumen. J. Appl. Microbiol. 107:1924-1934. https://doi .org/10.1111/j.1365-2672.2009.04376.x.

Moallem, U., D. Werner, H. Lehrer, M. Zachut, L. Livshitz, S. Yakoby, and A. Shamay. 2010. Long-term effects of ad libitum whole milk prior to weaning and prepubertal protein supplementation on skeletal growth rate and first-lactation milk production. J. Dairy Sci. 93:2639-2650. https://doi.org/10.3168/jds.2009-3007.

NRC. 2001. Nutrient Requirements of Dairy Cattle. 7th rev. ed. Natl Acad. Sci., Washington, DC.

Owens, F. 2005. Corn grain processing and digestion. Pages 1-21 in Proc. Minn. Nutr. Conf., St. Paul, MN. Accessed Dec. 21, 2019. https://www.biofuelscoproducts.umn.edu/sites/biodieselfeeds .cfans.umn.edu/files/ddgs-techinfo-pro-17.pdf.

Owens, F. N., D. S. Secrist, W. J. Hill, and D. R. Gill. 1997. The effect of grain source and grain processing on performance of feedlot cattle: A review. J. Anim. Sci. 75:868. https://doi.org/10.2527/ $1997.753868 \mathrm{x}$

Quigley, J. D., T. M. Hill, T. S. Dennis, F. X. Suarez-Mena, and R. L. Schlotterbeck. 2018. Effects of feeding milk replacer at 2 rates with pelleted, low-starch or texturized, high-starch starters on calf performance and digestion. J. Dairy Sci. 101:5937-5948. https:// doi.org/10.3168/jds.2017-13851.

Ramirez-Farias, C., K. Slezak, Z. Fuller, A. Duncan, G. Holtrop, and P. Louis. 2009. Effect of inulin on the human gut microbiota: stimulation of Bifidobacterium adolescentis and Faecalibacterium prausnitzii. Br. J. Nutr. 101:541-550. https://doi.org/10.1017/ S0007114508019880.

Robertson, J. B., and P. J. Van Soest. 1981. The Detergent System of Analysis and Its Application to Human Foods. Cornell University, Ithaca, NY.

Rosenberger, K., J. Costa, H. W. Neave, M. von Keyserlingk, and D. M. Weary. 2017. The effect of milk allowance on behavior and weight gains in dairy calves. J. Dairy Sci. 100:504-512. https://doi .org/10.3168/jds.2016-11195.

Sander, E. G., R. G. Warner, H. N. Harrison, and J. K. Loosli. 1959 The stimulatory effect of sodium butyrate and sodium propionate on the development of rumen mucosa in the young calf. J. Dairy Sci. 42:1600-1605. https://doi.org/10.3168/jds.S0022 -0302(59)90772-6.

Soberon, F., E. Raffrenato, R. W. Everett, and M. E. Van Amburgh. 2012. Preweaning milk replacer intake and effects on long-term productivity of dairy calves. J. Dairy Sci. 95:783-793. https://doi .org/10.3168/jds.2011-4391.

Soberon, F., and M. E. Van Amburgh. 2013. Lactation biology symposium: The effect of nutrient intake from milk or milk replacer of preweaned dairy calves on lactation milk yield as adults: A meta-analysis of current data. J. Anim. Sci. 91:706-712. https:// doi.org/10.2527/jas.2012-5834.

Steele, M. A., G. B. Penner, F. Chaucheyras-Durand, and L. L. Guan. 2016. Development and physiology of the rumen and the lower gut: Targets for improving gut health. J. Dairy Sci. 99:4955-4966. https://doi.org/10.3168/jds.2015-10351.

Stevenson, D. M., and P. J. Weimer. 2007. Dominance of Prevotella and low abundance of classical ruminal bacterial species in the bovine rumen revealed by relative quantification real-time PCR. Appl. Microbiol. Biotechnol. 75:165-174. https://doi.org/10.1007/ s00253-006-0802-y.

Terré, M., M. Devant, and A. Bach. 2007. Effect of level of milk replacer fed to Holstein calves on performance during the preweaning period and starter digestibility at weaning. Livest. Sci. 110:82-88. https://doi.org/10.1016/j.livsci.2006.10.001. 
Terré, M., M. Devant, and A. Bach. 2016. The importance of calf sensory and physical preferences for starter concentrates during pre-and postweaning periods. J. Dairy Sci. 99:7133-7142. https:// doi.org/10.3168/jds.2015-10682.

Van Keulen, J., and B. A. Young. 1977. Evaluation of acid-insoluble ash as a natural marker in ruminant digestibility studies. J. Anim. Sci. 44:282-287. https://doi.org/10.2527/jas1977.442282x.

Van Soest, P. J., J. B. Robertson, and B. A. Lewis. 1991. Methods for dietary fiber, neutral detergent fiber, nonstarch polysaccharides in relation to animal nutrition. J. Dairy Sci. 74:3583-3597. https:// doi.org/10.3168/jds.S0022-0302(91)78551-2.

Vital, M., C. R. Penton, Q. Wang, V. B. Young, D. A. Antonopoulos, M. L. Sogin, H. G. Morrison, L. Raffals, E. B. Chang, G. B. Huffnagle, T. M. Schmidt, J. R. Cole, and J. M. Tiedje. 2013. A gene-targeted approach to investigate the intestinal butyrateproducing bacterial community. Microbiome 1:8. https://doi.org/ 10.1186/2049-2618-1-8
Wildman, E. E., G. M. Jones, P. E. Wagner, R. L. Boman, H. F. Troutt Jr., and T. N. Lesch. 1982. A dairy cow body condition scoring system and its relationship to selected production characteristics. J. Dairy Sci. 65:495-501. https://doi.org/10.3168/jds .S0022-0302(82)82223-6.

Yu, Z., and M. Morrison. 2004. Improved extraction of PCR-quality community DNA from digesta and fecal samples. Biotechniques 36:808-812. https://doi.org/10.2144/04365ST04.

Zeng, Y., D. Zeng, Y. Zhang, X. Ni, Y. Tang, H. Zhu, H. Wang, Z Yin, K. Pan, and B. Jing. 2015. Characterization of the cellulolytic bacteria communities along the gastrointestinal tract of chinese mongolian sheep by using PCR-DGGE and real-time PCR analysis. World J. Microbiol. Biotechnol. 31:1103-1113. https://doi.org/ 10.1007/s11274-015-1860-Z.

Zhou, M., Y. Chen, and L. L. Guan. 2015. Rumen bacteria. Pages 79-95 in Rumen Microbiology: From Evolution to Revolution. Rumen Bacteria. Springer, Dordrecht, the Netherlands. 